\title{
Population Structure and Reproduction of Deuterodon langei Travassos, 1957 (Teleostei, Characidae) in a Neotropical Stream Basin from the Atlantic Forest, Southern Brazil
}

\author{
Jean Ricardo Simões Vitule ${ }^{1 *}$, Marcelo Rennó Braga ${ }^{1}$ and José Marcelo Rocha Aranha ${ }^{1}$ \\ ${ }^{1}$ Laboratório de Ecologia de Rios; Departamento de Zoologia; Setor de Ciências Biológicas; Universidade Federal \\ do Paraná; Centro Politécnico; 81531-990; Curitiba - PR - Brasil
}

\begin{abstract}
Aspects of the biology of D. langei were studied at different sites along a longitudinal gradient formed by the Ribeirão stream basin, a Neotropical stream of the Atlantic Forest, southern Brazil. Differences were observed in population structure and reproduction along the longitudinal gradient and during the study period. Juvenile fishes occurred in high abundance, mainly in the downstream site after the rainy months. Adults occurred mainly in the intermediate and upstream sites. During their life cycle, adults optimise their reproductive strategy by concentrating the reproductive period with total spawn in a short time interval before summer rains dragged the juvenile, larval forms and/or eggs downstream. The downstream site was characterized by a wide range of microhabitats (ex. submerged grass and shallow flooded area). Thus, the species used different portions of the basin in distinct stages of its life, being ecologically adapted to variation patterns in its temporal and physical environments.
\end{abstract}

Key Words: Characins, Tropical fish, Longitudinal segregation, Distribution, Reproductive period, Serra do Mar

\section{INTRODUCTION}

The Atlantic Forest is one of the richest and most threatened ecosystems of the planet (Myers et al., 2000). Several rivers flow through this ecosystem, which contain many endemic fish species (Menezes, 1996). The "Serra do Mar" is a 3000 kilometers mountain ridge covered with Atlantic Forest that extends along the Brazilian coast. Its network of littoral streams is poorly investigated (Mazzoni and Lobón-Cerviá, 2000). These streams are among the first environments to suffer from anthropic impacts, potentially threatening its fish fauna (Menezes et al., 1990; Menezes, 1996; Buckup, 1996; Faria and Marques, 1999, Vitule et al., 2006).

Tropical fishes have been demonstrated to be proportionally more diverse in species richness, ecological niches and trophic specialization than their temperate counterparts (Winemiller and Jepsen, 1998; Lowe-McConnell, 1999). More than $20 \%$ of all the known freshwater fishes species of the world are found in the Neotropics (Nelson, 2006).

* Author for correspondence 
The order Characiformes is one of the most diverse, presenting a wide variety of forms and biological and behavioral adaptations. In this order, the family Characidae has the largest number of known species and is widely distributed. The previously recognized subfamily Tetragonopterinae was considered the most successful characoid taxon, having invaded virtually all biotopes in the Neotropics (Vazzoler and Menezes, 1992; Lowe-McConnell, 1999; Nelson, 2006). The subfamily Tetragonopterinae has been abolished and most genera in this subfamily are now considered incertae sedis in Characidae (Lima et al., 2003).

Deuterodon Eigenmann, 1907 is an important genus with broad distribution in the Atlantic Forest, always being frequent and abundant in fish communities of littoral rivers, mainly in South and Southeastern Brazil. However, there are few studies of its ecology: Sabino and Castro (1990), Aranha et al. (1998), Mazzoni and Petito (1999), Aranha (2000), Vitule and Aranha (2002), Fogaça et al. (2003), Barreto and Aranha, (2005), Barreto and Aranha, (2006) and studies of population structure of D. langei does not exist. Deuterodon langei Travassos, 1957 (Characiformes, Characidae) is popularly called "lambari" and is one of seven currently recognized species of the genus, being endemic and very abundant in the coastal streams of Paraná and Santa Catarina, southern Brazilian States (Aranha et al., 1998; Aranha, 2000; Lucena and Lucena, 2002; Vitule and Aranha, 2002; Barreto and Aranha, 2005; Vitule et al., 2008).

$D$. langei is considered a resident of deep and/or shallow areas, lotic and/or lentic waters, and various types of substrates (Aranha et al., 1998; Fogaça et al., 2003; Barreto and Aranha, 2005). Studies on the diet of $D$. langei have been recently carried out in littoral streams of Paraná State. This species has been shown to be omnivorous/herbivorous (Aranha et al., 1998; Barreto and Aranha, 2006) and insectivorous with a predominance of aquatic insects in its diet (Fogaça et al., 2003). A trend toward an omnivory, with a decrease in animal items and an increase in vegetal items, has been shown to occur during ontogeny (Vitule and Aranha, 2002; Vitule et al., 2008).

All of the previous (except, Vitule et al., 2008) work on D. langei had a local focus, using fishes sampled from a single site, which has been a main problem to the understanding of its biology in the whole draining basin sites, considering that important spatial differences (longitudinal position, order magnitude, etc.) can be found along the same river (Vannote et al., 1980; Allan, 1995; Mazzoni and Lobón-Cerviá, 2000). Therefore, biological characteristics such as population structure and reproduction are fundamental information for the understanding of the community dynamics and conservation of the environment.

The aim of the present observational field study was to analyze the ontogenetic, spatial and temporal variation on the population structure and reproduction of $D$. langei at three distinct sample sites along a longitudinal gradient in a stream basin of the Atlantic Forest. Understanding the role of relevant fish species in structuring the fish assemblages and all stream community through their population structure and reproduction is fundamental to the habitat management and biodiversity conservation, especially in threatened and fragile Neotropical ecosystems.

\section{MATERIALS AND METHODS}

\section{Study area}

The study was conducted in the Ribeirão stream basin $\left(25^{\circ} 36^{\prime} \mathrm{S} ; 4^{\circ} 37^{\prime} \mathrm{W}\right)$ east side of the Serra do Mar, sub-basin of Paranaguá bay, Paranaguá city, Paraná. The spring is located on the Serra da Prata, $766 \mathrm{~m}$ above sea level. It is a short basin $(<30 \mathrm{~km})$ that drains directly into Paranaguá bay.

This region has a tropical, sub-equatorial, super humid, climate without dry season and frost. In general, annual rainfall rates are above $1000 \mathrm{~mm}$, and average annual temperatures range between $17^{\circ} \mathrm{C}$ and $21^{\circ} \mathrm{C}$ (IAPAR, 1978; Maack, 1981). Rainfalls are differently distributed during the year; January and February were the rainiest months, and July was the driest month during the investigation period (Fig. 1). As other coastal clear water streams in Atlantic Rain Forests, Ribeirão stream is dependent on the high rainfall of the area; it displays characteristics of rain waters, neutral $\mathrm{pH}$ and low level of nutrients. In the rainy season (summer), the river is subject to flash floods, significantly increasing in volume and flow of water that occur suddenly, causing a great alterations in the physical and biological parameters due to the water drag (Por, 1992). 


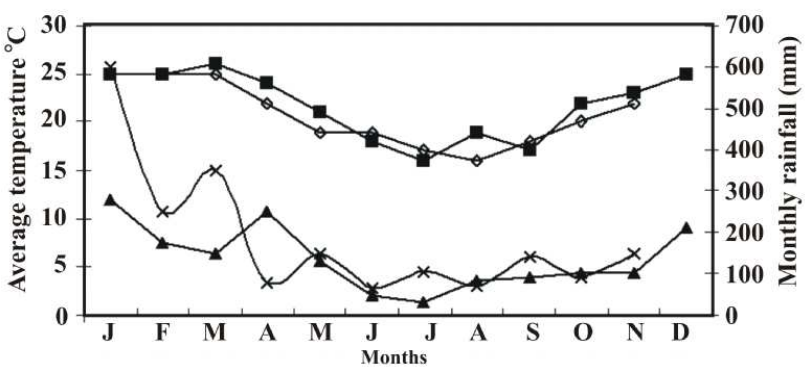

Figure 1 - Monthly rainfall in 2002 (filled triangles) and 2003 (line with X) in the study region, and average temperature in 2002 (filled squares) and 2003 (open squares). Source: IAPAR.

In general, the sample sections were 2 to $5 \mathrm{~m}$ wide and the depths were between $10 \mathrm{~cm}$ deep in the shallower margin to $1.8 \mathrm{~m}$ deep in the central deepest area. The bottom was mainly composed of sand, with some clay, leaves, gravel, rocks, trunks and branches. The vegetation of the river margin is composed of partially submerged shrubs, trees and grass which are usually covered with an algal layer. Aquatic macrophytes were rare in the studied area. Most of the sampling sites were very shaded and there were some beach formations.
Three sample points were established: site 1 (P1), an upstream first order section of the basin near its spring ( $\left.25^{\circ} 35^{\prime} 17^{\prime \prime} \mathrm{S} ; 48^{\circ} 38^{\prime} 01^{\prime \prime} \mathrm{W}\right)$; site 2 (P2), a second order middle section of the basin (25 36'02"S; 48 $\left.37^{\circ} 19^{\prime \prime} \mathrm{W}\right)$, and site 3 (P3), a downstream third order section of the basin

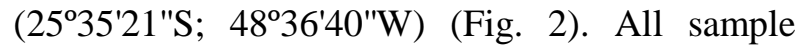
sites were less than $30 \mathrm{~m}$ above sea level. The main characteristics of are presented in Table 1.

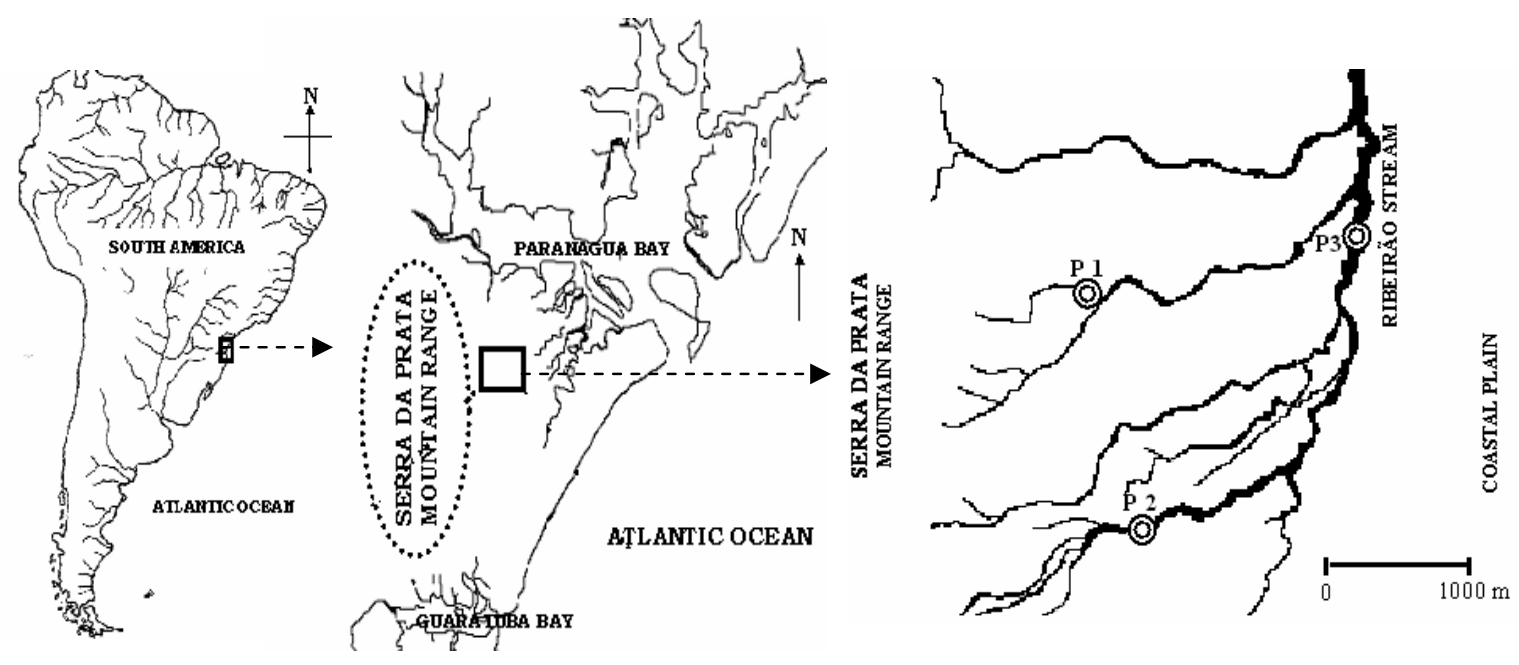

Figure 2 - Geographical location of the Ribeirão stream basin indicating the three sampling sites (P1, P2 and P3). 
Table 1 - Major characteristics of the three sites sampled along the catchment in Rio Ribeirão a Neotropical stream of Serra do Mar, Atlantic Forest, southern Brazil.

\begin{tabular}{lccc}
\hline Characteristics & Site 1 (p1) & Site 2 (p2) & Site 3 (p3) \\
\hline Order river & 1st Order & 2 st Order & 3 st Order \\
Longitudinal position & upstream & intermediary & downstream \\
WIDTH $(\mathrm{m})$ & $1-2$ & $2-4$ & $2-3$ \\
Max. Depth $(\mathrm{cm})$ & 80 & 180 & 100 \\
& sand & silt & silt \\
& gravel & sand & sand \\
Substrate types & cobble & gravel & cobble \\
& boulder & cobble & boulder \\
Run $(\%)$ & & boulder & intermediary \\
Pool $(\%)$ & intermediary & intermediary & intermediary \\
Riparian vegetation $(\%)$ & high & high & high \\
Instream vegetation $(\%)$ & intermediary & intermediary & high \\
Cover vegetation $(\%)$ & low & intermediary & high \\
\hline
\end{tabular}

\section{Fish sampling and data analyses}

Fishes were sampled monthly from January 2002 to February 2003 with three hours of effort at each sample site. The samples were obtained using sieves, a small trawl net $1.30 \times 1.40 \mathrm{~m}$ with $2 \mathrm{~mm}$ mesh and five gill nets $1.50 \times 5 \mathrm{~m}$, three with 15 $\mathrm{mm}$ mesh and two with $20 \mathrm{~mm}$ mesh between consecutive knots.

In pilot samples at the three sampling sites (P1, P2 and P3), and at different sites of the basin, it was observed that the electric fishing method had size selectivity for $D$. langei, underestimating larger specimens (> $6.0 \mathrm{~cm})$. For that reason, only traditional fishing methods (cited above) were used, showing more efficiency in obtaining a homogeneous sampling.

Samples were always taken during the daytime, since personal underwater observations and information from the literature (Fogaça et al., 2003; Sabino and Castro, 1990; Barreto and Aranha 2005; Vitule et al., 2008) indicated that $D$. lange $i$ were active at daytime.

In the field, specimens were stored in the ice. In laboratory, they were measured for total length ( $\mathrm{Lt}$ in $\mathrm{cm}$ ) and were weighed (Wt mass in $\mathrm{g}$ ). With the aid of a light microscope, fish specimens were identified, dissected and sex and gonad development stages were determined.

All the captured specimens were used in the population structure study, but only individuals with a well-preserved gonad were used for the reproduction analyses.

\section{Data analysis}

\section{Population Structure}

With respect to their length class and juvenile/adult stage all the 1071 captured specimens were analyzed. Size varied from the 1.2 $\mathrm{cm}$ to $12.6 \mathrm{~cm}$ of total length $(\mathrm{Lt})$. Twelve length classes were established according to the methodology proposed from Sturges (Vieira, 1991), with closed intervals of $1 \mathrm{~cm}$ and each interval with a code: $1(1.1-2.0 \mathrm{~cm}), 2(2.1-3.0$ $\mathrm{cm})$, and so on until $12(12.1-13.0 \mathrm{~cm})$.

The length class frequency, juveniles $\left(<\mathrm{L}_{50}\right)$ to adult $\left(>\mathrm{L}_{50}\right)$ and sex ratio were studied with respect to sample sites and season and the differences were tested with $\chi^{2} \quad(\alpha=0.05)$ statistical test (Zar, 1999).

Weight/length relationship was obtained for the males and females separately and compared to the expression of males and females together. The method proposed by Takeuti et al. (1999) allows, with a 95\% confidence interval, for the determination of the males and females, it analyzed together or separately.

\section{Reproduction}

With respect to their reproduction analyses, a total of 705 individuals were used, of which 283 were males and 250 females. One hundred and seventy two specimens were too young to determine their sex.

The identification of gonadal developmental stages was made using gonad characteristics such as size, shape, color, vascularization, position and oocyte 
color, according to the typical characteristics of the studied species (Vitule et al., 2007).

Female stages were: juveniles (immature) $=$ very small gonad, translucent ovary with oocytes invisible to the naked eye; early maturation = intermediate size ovary with very small pale-white oocytes visible to naked eye; advanced maturation $=$ more developed ovary with yellow oocytes; ripe ovary $=$ fully developed ovary filling ventral region of the abdominal cavity, eggs were postvitellogenic (diameter $0.4-1.0 \mathrm{~mm}$ ) and expulsed when external pressure was applied to the ventrum; postspawning = ovary was very flaccid and hemorrhagic with little significant presence of ripe oocytes. Male maturation stages were: juveniles (immature) $=$ undeveloped testis consisting of a very small translucent filament; early maturation $=$ intermediate size testis with translucent white colour; advanced maturation = large testis, opaque white colour; ripe testis = fully developed testis, pressure applied to ventrum expulses white milt; and postspawning = flaccid and hemorrhagic testis with little milt (Vitule et al., 2007).

The reproductive period was defined using gonad development stages frequency, average gonossomatic relationship (RGS) and gonad index (IG), according to Vazzoler (1996).

The length at the first onset of sexual maturity $\left(\mathrm{L}_{50}\right)$ and the length when $100 \%$ of individuals were adults $\left(\mathrm{L}_{100}\right)$ were calculated accordingly to Vazzoler (1981).

The intensity of reproductive activity was estimated at each sample site using reproductive activity index (IAR) according to Agostinho et al. (1991). The IAR identifies portions of the population or community with greater reproductive activity (Vazzoler, 1996). Usually the index is applied to distinct rivers and, therefore, to different populations. In this work the IAR was applied on different parts of the same basin and, therefore, to the same population. The objective was to compare the reproductive activity between the sample sites. Although the defined limit values were not necessarily suitable for all the fish species, the index has been used to define areas where populations put more effort on the reproduction.

\section{RESULTS}

\section{Population structure}

The length classes with higher relative frequency $(>15 \%)$ at each sample site were three and four for sample site 1 , class nine for sample site 2 and classes two and three for the sample site 3 . There was a predominance of larger specimens at sample site 2 and smaller specimens at sample site 1 and mainly at site 3 (Fig. 3).

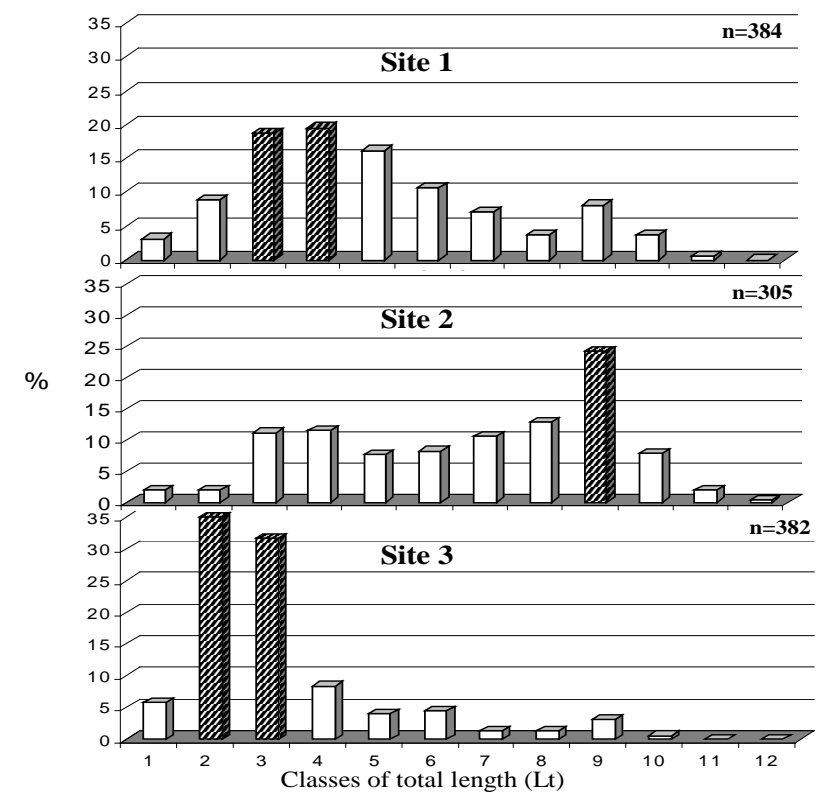

Figure 3 - Size structure (Lt) of $D$. langei in three sampling sites of Ribeirão stream basin during the study period. The lines in the bars indicate the high frequencies $(>15 \%)$. 
The distribution of smaller fishes (length classes 1 , 2 and 3) in the last four months of the study (November and December 2002, January and February 2003) was not random $\left(\chi^{2}=72.74\right.$; $\mathrm{p}<0.05$ ), showing a decrease in juveniles fish at sample site 1 and a corresponding increase at sample site 3, along the rainy months, indicating the drastic drift changes determined by the water discharges of the rainfalls that occurred during the tropical storms in the summer (Fig. 4).

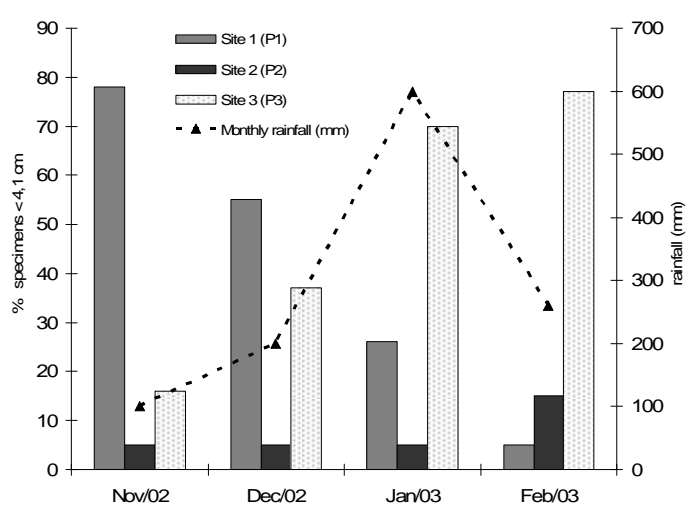

Figure 4 - Distribution of D. langei with less to $4.1 \mathrm{~cm}$ of Lt (total length classes 1, 2 and 3) in three sampling sites of Ribeirão stream basin from November 2002 to February 2003, periods with discrepant rainfall.

The proportion of the males and females, tested by $\chi^{2}$, was the same $1: 1 \quad(p<0.05)$ for the whole sample, between the sample sites, seasons, months and length classes. Analyzing the whole sample, the frequency of juveniles was higher than that of adults with juveniles ratio of $>60 \%$ at sites 1 and 3 , contrasting with sample site 2 in which adult ratio was $>75 \%$ (Fig. 5).

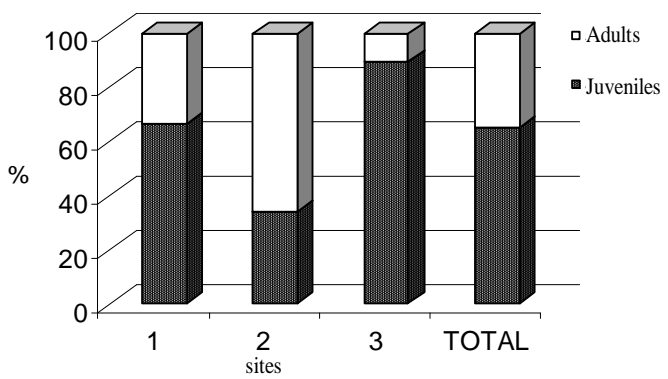

Figure 5 - Percentage of juveniles and adults of $D$. langei in relation to the sites for total sampled from the Ribeirão stream basin during the study period.

The distribution of juveniles/adults between the sample sites was not random $\left(\chi^{2}=228.27 ; p<0.05\right)$. The proportion of juveniles and adults was not random $\left(\chi^{2}=31.93 ; \mathrm{p}<0.05\right)$, showing a greater over time frequency of juveniles fish $(>70 \%)$ during the first semester of 2002. From the spring on, adults were more frequent than juveniles $(>50 \%)$.

A comparison of seasons variation at each sample site demonstrated that the proportion of juveniles was greater at sample site $1(>70 \%)$ in the first nine months (summer, autumn and winter of 2002) (Fig. 6). Its proportion reduced to less than $50 \%$ in the summer of $2003\left(\chi^{2}=39.79 ; p<0.05\right)$.

At sample site 2, the presence of adults was always (>50\%), reaching more than $75 \%$ in the last six months (spring/2002 and summer/2003, $\chi^{2}$ $=19.25 ; \quad \mathrm{p}<0.05)$. Juveniles fishes were predominant $(>70 \%)$ during the whole study. Although, the proportion of the adults increased in 
the spring $(>25 \%)$ in relation to other times of the year $\left(\chi^{2}=26.54\right.$; $<<0.05$, Fig. 6$)$.

The straight lines obtained from $\mathrm{Wt} / \mathrm{Lt}$ relation for the males and females did not overlap in their confidence intervals. Therefore the equations of $\mathrm{Wt} / \mathrm{Lt}$ were estimated separately for each sex: Females $\mathrm{Wt}=0.008 . \mathrm{Lt}^{3.188}\left(\mathrm{r}^{2}=0.917\right)$ and males $\mathrm{Wt}=0.009 . \mathrm{Lt}^{3.138}\left(\mathrm{r}^{2}=0.979\right)$.

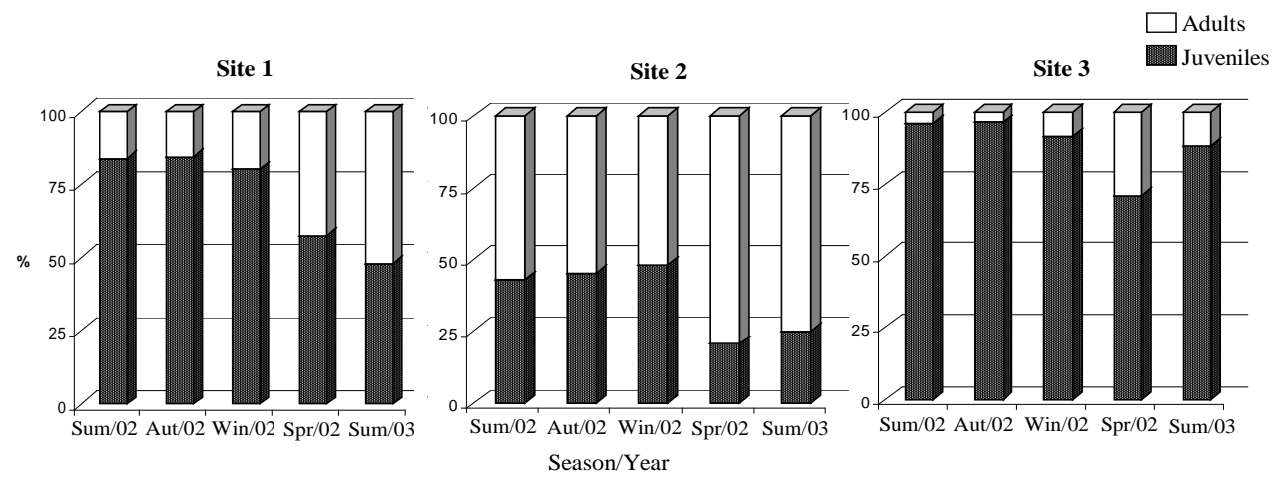

Figure 6 - Percentage of juveniles and adults of D. langei along the seasons in three sampling sites of the Ribeirão stream basin.

\section{Reproduction}

The males and females of $D$. langei had gonads with band and elongated form when immature. When in advanced development stages, the gonads had the shape of an elongated leaf. They were located in the laterals and back of the abdominal cavity and attached to the peritoneum membrane.

When immature, the gonads were translucent and difficult to locate, requiring the use of a microscope with transmitted light to identify the first stages of gonad development.

The frequency of gonad development stages between the months indicates the existence of ripe males and females during most of the study. Ripe females occurred in February 2002 and from August 2002 to February 2003, with the highest peak in November 2002. Ripe male distribution was similar, with a peak in December 2002. Spawned females occurred in February and December 2002, and in February 2003. Males with empty gonads were found in January, February and March 2002; January and February 2003 (Fig. 7). There data suggesting that the reproductive period occurred from the end of spring to the end of summer between November 2002 and February 2003.

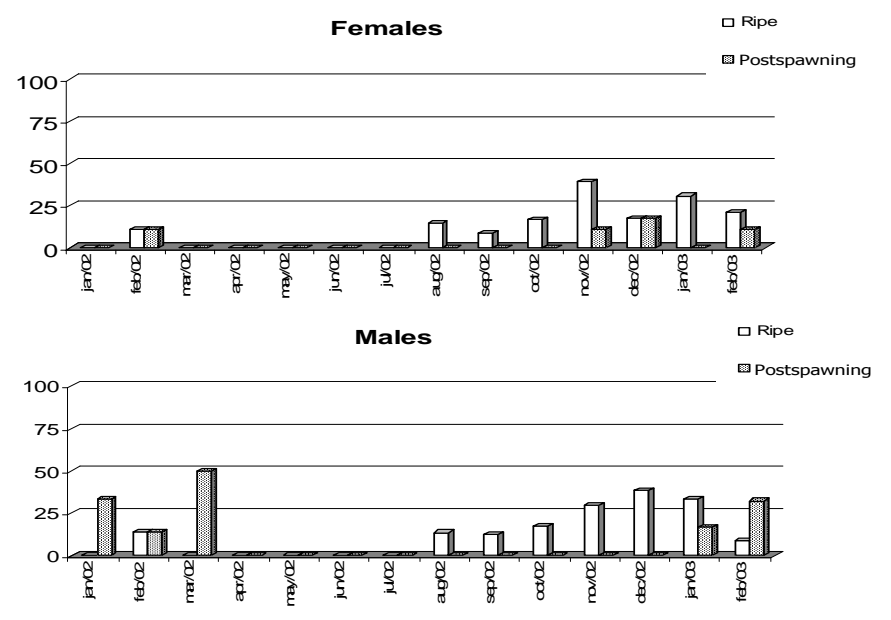

Figure 7 - Monthly percentage of ripe and postspawing gonad maturation stages of males and females $D$. langei in Ribeirão stream basin. 
Average values of RGS and IG showed a similar pattern for the males and females with a progressive increase from July 2002 until reaching the highest values in October and November of 2002 for the females and November and December 2002 for the males (Fig. 8).

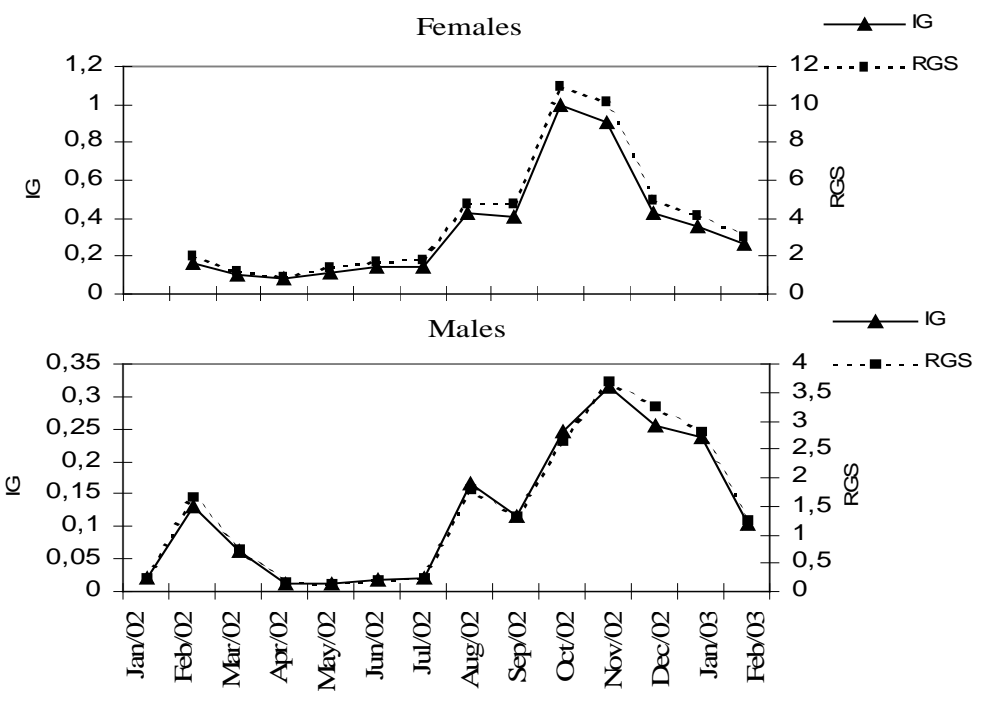

Figure 8 - Monthly trends in RGS and IG for males and females D. langei in the Ribeirão stream basin.

The average length at the first sexual maturity $\left(\mathrm{L}_{50}\right)$ was in the same length class $6(6.1-7.0 \mathrm{~cm}$ $\mathrm{Lt})$ for the males and females, the $\mathrm{L}_{100}$ was inside length class 8 (8.1-9.0 cm - Lt, Fig. 9).

The reproductive activity index (IAR) for the species at the three sample sites presented significant differences. At sample site 1, the IAR was 11.20 (intense); at sample site 2 it was 22.10 (very intense) and at sample site 3 it was 6.54 (moderate). Comparatively, the greatest reproductive activity occurred at sample site 2 .

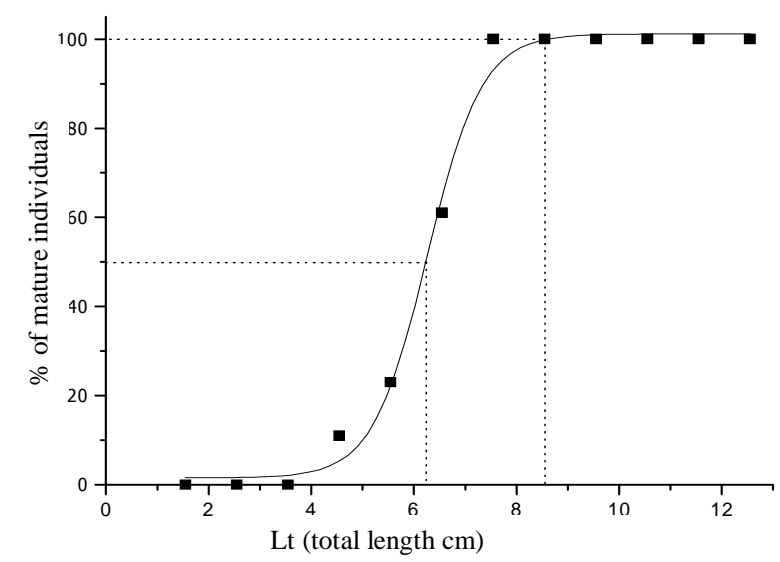

Figure 9 - Estimative of $\mathrm{L}_{50}$ and $\mathrm{L}_{100}$ for D. langei population of the Ribeirão stream basin. 


\section{DISCUSSION}

D. langei was a frequent and abundant species during the whole period of study and certainly could be considered one of the most important species from the Ribeirão stream basin fish assemblage. The same conclusions were made for D. langei in others streams basins in Paraná (Aranha, 2000; Fogaça et al., 2003; Barreto and Aranha, 2005) and for species of Deuterodon genus (Sabino and Castro, 1990; Mazzoni and Petito, 1999; Mazzoni and Lobón-Cerviá, 2000).

$D$. langei presented a great amplitude of total length ( $\mathrm{Lt}-1.1$ to $12.6 \mathrm{~cm}$ ) along the Ribeirão basin, thus confirming the results of Vitule and Aranha (2002) which were obtained in a single electric fishing sample in July 1995 (fishes with a standard length amplitude between 2.1 and 9.9 cm). Sabino and Castro (1990), studying D. iguape also found a standard length amplitude between 2.8 and $9.7 \mathrm{~cm}$. In contrast, Mazzoni and Petito (1999) studying Deuterodon sp. found length amplitude between 2.3 and $6.0 \mathrm{~cm}$, which could be a characteristic of the species or a consequence of sampling methods.

The length class distribution along different parts of Ribeirão river basin was distinct. At sample site 1 , the size classes distributed more uniformly; at sample site 2 , there were a greater quantity of larger individuals and at sample site 3 small size fishes predominated. This distribution can be a consequence of variations in the temporal and physical environments.

Deeper places (> $1 \mathrm{~m}$ ) with branches and submerged vegetation were the preferential microhabitat (Barreto and Aranha, 2005) mainly of larger adults $D$. langei, and such features were found in sample site 2 where larger individuals predominated. The predominance of smaller fishes at sample site 3 could be a reflex of the great extension of riparian vegetation and submerged marginal vegetation in very shallow marginal areas. Sabino and Castro (1990) described the preference of juveniles $D$. iguape for lentic and shallow environment near the marginal vegetation.

In rivers with great floodplain areas, time and space variation in ichthyofauna has been related to migratory process in association with feeding and reproductive biological aspects (Knöppel, 1970; Goulding, 1980; Winemiller and Jepsen, 1998; Lowe-McConnell, 1999).
In this study, the greater concentration of juveniles fishes in the downstream portion of the river could be related to the physical events such as the drag provoked by summer rain, which caused flash floods. Small individuals, with less swimming capacity, larval forms and/or eggs could be more easily dragged than the larger fishes, which could migrate to upstream regions. Patterns like this were proposed by other authors such as Menezes and Caramaschi (1994) and Braga et al. (2008) for the coastal river species. Similar longitudinal segregation was proposed for Astyanax janeiroensis Eigenmann, 1908, other Characidae related to Atlantic forest streams, where an upstream spawn migration and downstream drag of eggs and larval forms were described (Mazzoni et al., 2004).

When comparing the juveniles frequency at each sample site, the drag effect was evident in the rainy season when flash floods were more frequent, the number of small fishes decreased at sample site 1 and increased at sample site 3 .

The sexual proportion was statistically closed to $1: 1$, in contrast with Mazzoni and Petito (1999) results, that despite a small sample size, proposed sexual dimorphism with the females reaching around two centimeters more than the males for Deuterodon $\mathrm{sp}$. Sexual poportion differences were also observed for other genera taxonomically and ecologically related to $D$. langei. Astyanax scabripinis paranae, for example, showed a greater proportion of female in some periods of the year (Barbieri, 1992).

It is likely that in some cases (e.g. Mazzoni and Petito, 1999) sexual proportion differences can be more related to the fishing methodology than to the biological aspects.

The absence of partially spawned females and the occurrence of well defined RGS and IG peaks suggesting that $D$. langei has a total spawn, agreeing with results of Mazzoni and Petito (1999) for Deuterodon sp.

The average length when $50 \%$ of population had its first maturation $\left(\mathrm{L}_{50}\right)$ was relatively high (between 6.1 and $7.0 \mathrm{~cm}$ ) for the males and females. Mazzoni and Petito (1999) defined a $\mathrm{L}_{50}$ of $2.8 \mathrm{~cm}$ for Deuterodon sp. The higher values could be a consequence of greater size of $D$. langei, as the $\mathrm{L}_{50}$ in both studies occurred with approximately $50 \%$ of the higher total length.

The reproductive period established with different methodologies was supported by the entry of smaller fishes into the population, which occurred 
in a short time from the end of spring until summer. Mazzoni and Petito (1999) obtained a distinct result for Deuterodon sp. describing a reproductive activity along the whole year.

Long reproductive periods have been related to highly unstable environment (Kushlan, 1976; Harrell, 1978; Garutti, 1989; Mazzoni and Petito, 1999; Menezes and Caramaschi, 2000). This study found a short reproductive period. Although the Ribeirão stream basin presents a strong flood pulse that causes changes of habitat structure (Gonçalves and Aranha, 2004; Braga et al., 2008; Vitule et al., 2008), such floods occurs in a well defined seasonal way (mainly January, February and March).

It seems that $D$. langei in some way adapted itself to anticipate those events. Thus, $D$. langei maximized the capacity of its reproductive strategy concentrating the reproductive period, with total spawn in the space of time before the summer rains.

The reproductive activity index (IAR) indicated that $D$. langei reproduced in the whole basin, although reproductive activity was more intense in the upstream regions, thus the predominance of juveniles fishes at sample site 3 could be related to drag. The increase of juveniles from the upstream (sample site 1) to the downstream (sample site 3) during the rainy season was evident (Fig. 4). That way $D$. langei could concentrate the reproductive period in the upstream sites at the beginning of summer rains, which carried juveniles, larval forms and/or eggs to sample site 3 where it had greater variability of microhabitats (flooded and submerged grass in very shallow marginal areas) where the juveniles fishes could find shelters from the predators and feeding areas with its preferred food such as insects and other invertebrates found in submerged vegetation (Vitule and Aranha, 2002; Vitule et al., 2008).

As $D$. langei, grew it became able to explore new food and spatial resources. Larger fishes occupied lentic and deeper environments upstream, where they reproduced, completing the life cycle of the species. According to the scenario proposed for the population dynamics of $D$. langei at Ribeirão stream basin, the species utilized different sites of the basin in distinct stages of its life, being ecologically adapted to the patterns of variations in its physical environments. Thus, the constant exploration now occurring mainly in the downstream areas could result in great impact on
D. langei population along the whole basin community.

\section{ACKNOWLEDGEMENTS}

We thank Márcio R. Pie, Mozart Braga, Viviane Prodocimo and Luís Amilton Foester for help with the English translation and suggestions regarding the manuscript. Instituto Agronômico do Paraná (IAPAR) for rainfall data. Conselho Nacional de Desenvolvimento Científico e Tecnológico (CNPq), provided financial support.

\section{RESUMO}

Aspectos da biologia de $D$. langei foram estudados em diferentes locais da bacia do rio Ribeirão, um riacho litorâneo da Floresta Atlântica do sudeste do Brasil. Foram observadas diferenças na estrutura da população e na reprodução, ao longo do gradiente longitudinal da bacia e do período de estudo. Os peixes juvenis ocorreram em grande abundância, principalmente no trecho a jusante da bacia, após os meses mais chuvosos. Adultos ocorreram principalmente nos trechos intermediários e a montante. Não houve diferença significativa na relação sexual entre os locais amostrados, estações do ano, meses e classes de comprimento. O comprimento médio de primeira maturação (L50) foi o mesmo para machos e fêmeas, entre 6,1 e $7,0 \mathrm{~cm}$ de comprimento total (Lt). O período reprodutivo foi curto (entre o final da primavera e início do verão), antes dos meses mais chuvosos, com desova total. O Índice de Atividade Reprodutiva (IAR) indicou que $D$. langei reproduz em toda a bacia, porém a atividade reprodutiva é mais intensa nos trechos mais a montante da bacia. O período chuvoso e as chuvas torrenciais se mostraram fatores abióticos muito importantes para a dinâmica da população. Durante seu ciclo de vida os adultos maximizam sua estratégia reprodutiva concentrando o período reprodutivo, com desova total em um curto espaço de tempo antes das chuvas de verão que carregam juvenis, formas larvais e/ou ovos para as regiões a jusante onde existe uma ampla quantidade de micro-ambientes (gramíneas submersas e áreas rasas e calmas). Desta forma a espécie estudada utilizou diferentes porções da bacia em distintos estágios de seu ciclo de vida, demonstrando estar 
ecologicamente adaptada às variações temporais e físicas do ambiente.

\section{REFERENCES}

Agostinho, A. A., Suzuki, H. I., Sampaio, A. A. and Borjes, J. D. R. (1991), Índice de atividade reprodutiva: uma proposta para avaliação da atividade reprodutiva em peixes. In: IX Encontro Brasileiro de Ictiologia. Maringá: UNIMAR, pp. 53.

Allan, J. D. (1995), Stream Ecology: Structure and Function of Running Waters. Chapman and Hall, London.

Aranha, J. M. R. (2000), A influência da instabilidade ambiental na composição e estrutura trófica da ictiofauna de dois rios litorâneos. Ph.D. thesis. São Carlos, São Paulo: Universidade Federal de São Carlos. $130 \mathrm{pp}$

Aranha, J. M. R., Takeuti, D.F. and Yoshimura, T. (1998), Habitat use a food partitioning of the fishes in a coastal stream of Atlantic Forest, Brazil. Revista de Biología Tropical, 46, 951-959.

Barbieri, G. (1992), Biologia de Astyanax scabrippinis paranae (Characiformes, Characidae) do ribeirão do Fazzari. São Carlos. Estado de São Paulo. I. Estrutura populacional e crescimento. Revista Brasileira de Biologia, 52, 479-588.

Barreto, A. P. and Aranha, J. M. R. (2005). Assembléia de peixes de um riacho da Floresta Atlântica: composição e distribuição espacial (Guaraqueçaba, Paraná, Brasil). Acta Scientiarum Biological. Science, 27, 153-160.

Barreto, A. P. and Aranha, J. M. R. (2006). Alimentação de quatro espécies de Characiformes de um riacho da Floresta Atlântica, Guaraqueçaba, Paraná, Brasil. Revista Brasileira de Zoologia 23, 779-788.

Buckup, P. (1996), Biodiversidade dos peixes da mata atlântica. In Workshop "Padrões de biodiversidade da mata atlântica do sudeste e sul do Brasil". Campinas, São Paulo. Base de dados tropical: http://www.bdt.org.br/workshop/mata.atlantica.

Braga, M. R., J. R. S. Vitule and Aranha, J. M. R. (2008), Reproduction Period of Mimagoniates microlepis (Steindachner, 1876) (Characidae, Glandulocaudinae) from an Atlantic Forest Stream in Southern Brazil. Brazilian Archives of Biology and Technology, 51, 345-351.

Faria, A.P. and Marques, J.S. (1999), O desaparecimento dos pequenos rios brasileiros. Ciência Hoje, 148, 56-61.

Fogaça, F. N. O., Aranha J. M. R. and Esper, M. de L. P. (2003), Ictiofauna do Rio do Quebra (Antonina, PR, Brasil): ocupação espacial e hábito alimentar. Interciência, 28, 168-173.
Garutti, V. (1989), Contribuição ao conhecimento reprodutivo de Astyanax bimaculatus (Ostariophysi, Characidae), em cursos de água da bacia do rio Paraná. Revista Brasileira de Biologia, 49, 489-495.

Gonçalves, F. B. and Aranha, J. M. R. (2004), Ocupação espaço-temporal pelos macroinvertebrados bentônicos na bacia do rio Ribeirão, Pranaguá, Paraná (Brasil). Acta Biológica Paranaense, 33, 181-190.

Goulding, M. (1980), The fishes and the forest. Berkeley: University of California Press. 280 pp.

Harrell, H. L. (1978), Response of the Devil's river (Texas) fish community to flooding. Copeia, 1, 6068.

IAPAR (1978), Cartas climáticas básicas do Estado do Paraná. Instituto Agronômico do Paraná, Londrina.

Knöppel, H. A. (1970), Food of central Amazonian fishes: contribution to the nutrient-ecology of Amazonian rain forest streams. Amazoniana, 2, 257352.

Kushlan, J. A. (1976), Environmental stabilitity and fish community diversity. Ecology, 57, 821-825.

Lima, F. C. T., Malabarba L. R., Buckup P. A., Pezzi da Silva, J. F., Vari, R. P., Harold, A., Benine, R., Oyakawa, O. T., Pavanelli, C. S., Menezes, N. A., Lucena, C. A. S., Malabarba, M. C. S. L., Lucena, Z. M. S., Reis, R. E., Langeani, F., Cassati L. and Bertaco, V. A. (2003). Genera Incertae Sedis in Characidae. In: Reis, R. E., Kullander S. O.and Ferraris, C. J. Jr. (eds), Checklist of the Freshwater Fishes of South and Central America. EDIPUCRS, Porto Alegre, pp. 106-168.

Lowe-McConnell, R. H. (1999), Estudos ecológicos de comunidades de peixes tropicais. Edusp, São Paulo.

Lucena, C. A. S. and Lucena, Z. M. S. (2002), Redefinição do gênero Deuterodon Eigenmann, 1907 (Ostariophysi: Characiformes: Characidae). Comunicações do Museu de Ciências e Tecnología da PUCRS, 15, 113-135.

Maack, R. (1981), Geografia física do Estado do Paraná. J. Olympio, Rio de Janeiro.

Mazzoni, R. and Petito, J. (1999), Reproductive biology of a Tetragonopterinae (Osteichthyes, Characidae) of the Ubatiba fluvial system, Maricá-RJ. Brazilian Archives of Biology and Technology, 42, 455-461.

Mazzoni, R. and Lobón-Cerviá, J. (2000), Longitudinal structure, density and production rates of a neotropical stream fish assemblage: the river Ubatiba in the Serra do Mar, southeast Brazil. Ecography, 23, 588-602.

Mazzoni, R., Schubart S. A. and Iglesias-Rios, R. (2004), Longitudinal segregation of Astyanax janeiroensis in Rio Ubatiba: a Neotropical stream of south-east Brazil. Ecology of Freshwater Fish, 13, 231-234.

Menezes, M. S. and Caramaschi, E. P. (1994), Característica reprodutivas de Hypostomus grupo $H$. Punctatus no rio Ubatiba, Maricá, (RJ) (Osteichthyes, 
Siluriformes). Revista Brasileira de Biologia, 54, 503-513.

Menezes, M. S. and Caramaschi, E. P. (2000), Longitudinal Distribution of Hypostomus punctatus (Osteichthyes,Loricariidae) in a Coastal Stream from Rio de Janeiro, Southeastern Brazil. Brazilian Archives of Biology and Technology, 43, 221-227.

Menezes, N. A., (1996), Padrões de distribuição da biodiversidadedos da mata atlântica do sul e sudeste brasileiro: peixes de água doce. In: Workshop "Padrões de biodiversidade da mata atlântica do sudeste e sul do Brasil'. Campinas, São Paulo. Base de dados tropical: http://www.bdt.org.br/workshop/mata.atlantica.

Menezes, N. A., Castro, R. M. C., Weitzmam, S. H. and Weitzmam, M. J. (1990), Peixes de riacho da floresta costeira atlântica brasileira: um conjunto pouco conhecido e ameaçado de vertebrados. In: Watanabe S. (coord.) Anais do II Simpósio de Ecossistemas da Costa Sul e Sudeste do Brasil. Águas de Lindóia: São Paulo, pp. 290-295.

Myers, N., R. A. Mittermeier, C. G. Mittermeier, G. A. Fonseca and Kent, J. (2000), Biodiversity hotspots for conservation priorities. Nature, 403, 853-858.

Nelson, J. S. (2006), Fishes of the world. John Wiley and Sons, New York.

Por, F.D. (1992), Sooretama, the Atlantic rain forest of Brazil. SPB Academic Publishing, New York.

Sabino, J and Castro, R. C. (1990), Alimentação, período de atividade e distribuição espacial dos peixes de um riacho de floresta atlântica (sudeste do Brasil). Revista Brasileira de Biologia, 50, 23-36.

Takeuti, D. F., J. R. Verani, J. M. R. Aranha and Menezes, M. S. (1999), Population structure and condition factor of Pseudotothyris obtusa (Loricariidae, Hypoptopomatinae), from three coastal streams in Southern Brazil. Brazilian Archives of Biology and Technology, 42, 397-403.

Vannote, R. L., G. W. Minshal, K. W. Cummins, K. W. Sedell and Cushing, C. E. (1980), The river continuum concept. Canadian Journal of Fisheries and Aquatic Sciences, 37, 130-137.
Vazzoler, A. E. A. M. (1981), Manual de Métodos para Estudos Biológicos de Populações de Peixes, Reprodução e Crescimento. CNPq. Programa Nacional de Zoologia, Brasília.

Vazzoler, A. E. A. M. (1996), Biologia da reprodução de peixes teleósteos: teoria e prática. EDUEM, Maringá.

Vazzoler, A. E. A. de M. and Menezes, N. A. (1992) Síntese de conhecimento sobre o comportamento reproductivo dos Characiformes da América do Sul (Teleostei: Characiformes). Revista Brasileira de Biologia, 52, 627-540.

Vieira, S. (1991), Introdução a Bioestatística. Ed. Campus, Rio de Janeiro.

Vitule, J. R. S. and Aranha, J. M. R. (2002), Ecologia alimentar do lambari, Deuterodon langei Travassos, 1957 (Characidae, Tetragonopterinae), de diferentes tamanhos em um riacho da Floresta Atlântica, Paraná (Brasil). Acta Biológica Paranaense, 31, 137-150.

Vitule, J. R. S., Umbria, S.C. and Aranha, J. M. R. (2006), Introduction of the African catfish Clarias gariepinus (Burchell, 1822) into Southern Brazil. Biological Invasions, 8, 677-681.

Vitule, J. R. S., Gazola-Silva, F. F. and Aranha, J. M. R. (2007), Desenvolvimento gonadal de Deuterodon langei Travassos (Teleostei: Characidae). Acta Biológica Paranaense, 36, 113-119.

Vitule, J. R. S., M. R. Braga and Aranha J. M. R. (2008). Ontogenetic, spatial and temporal variations ion the feeding ecology of Deuterodon langei Travassos, 1957 (Teleostei: Characidae) in a Neotropical stream from the Atlantic rainforest, southern Brazil. Netropical Ictiology, 6(2):211-222.

Winemiller, K. O. and Jepsen, D. B. (1998), Effects of seasonality and fish movement on tropical river food webs. Journal of Fish Biology, 53, 267-296.

Zar, J. H. (1999), Biostatistical analysis. Prentice Hall, New Jersey. 